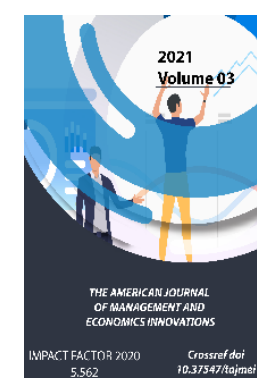

\title{
Socio-Economic Changes In The City Of Kokand (Late 19th Century And Early 20th Century)
}

\author{
Azamjon Yusupov \\ Senior Teacher, Fergana Polytechnic Institute, Uzbekistan
}

Journal Website:

https://theamericanjou

rnals.com/index.php/ta

jmei

Copyright: Original

content from this work

may be used under the

terms of the creative

commons attributes

4.0 licence.

\section{ABSTRACT}

The article attempts to reveal the socio-economic changes that took place in Kokand in the late 19th early 2oth centuries, based on archival data and historical sources written before the revolution and during the Soviet era.

\section{KEYWORDS}

Kokand, Fergana Valley, Great Silk Road, Kokand Khanate, Kashgar, urban planning, handicrafts, silk, silkworm breeding, trade, market, ethnic composition of the population.

\section{INTRODUCTION}

Kokand is an ancient and beautiful city that sometimes gets lost against the backdrop of Bukhara or Samarkand. Kokand is located in the east of Uzbekistan, in the southwestern part of the Fergana Valley. It is located within $228 \mathrm{~km}$ southeast of the capital of Uzbekistan Tashkent, $115 \mathrm{~km}$ west of Andijan and $88 \mathrm{~km}$ west of Fergana. During the times of the khanate of the same name, the city of Kokand flourished, and this can still be seen from its luxurious architectural heritage of those times - tiled mosques, tombs, madrasahs.
The first written mentions of Kokand date back to the 2nd century BC. However, he gained fame only in the 10th century: then the settlement turned out to be on the Great Silk Road from China to India and from Persia, which made it a rather significant trade center. In the 13th century, the city was destroyed by the Mongol tribes and lost its significance for a long time. In the 18th century, the city was revived and became the capital of the Kokand Khanate, and this was the period of real prosperity of Kokand. 
The Russian traveler, ethnographer G.N. Potanin, who personally visited the XIX century himself, writes: "... the city suffered great damage over time, this can be seen from the preserved, but destroyed ancient monuments" [32: p.282].

In addition, a lot of information about the city is given by Nalivkin, an expert on the history of the Turkestan cities [8:]. (Although his book is not devoid of some inaccuracies - author's note).

However one of the authors of many books on the history of Kokand, Doctor of History, prof. Kh. Bobobekov also writes that in the 10th century Arab authors were familiar with this city [1: p.7].

Currently there are a lot of books and other information from different authors about the history of this city, both in Russian-language literature and in the works of local authors of the Kokand historical school of the 18th-19th centuries, whose works are written in the Old Uzbek script.

Naturally, in the archival funds of the National Archives of Uzbekistan, a number of funds also store valuable information and materials both on the history of Kokand and on the history of the Kokand Khanate. Here two important roads leading to the Fergana Valley from Tashkent and Khujand merged.

The famous orientalist V.V. Velyaminov-Zernov, turning his attention to the development of trade relations, noted that the Kokand Khanate has trade communications through KokandKashgar [2: p.130].

Until 1876, the cit y of Kokand was the capital and large city of the Kokand Khanate. After the abolition of the khanate, the city entered as one of the cities in the Fergana region of the Turkestan governor-general.

Since that time, the city of Kokand, lost its significance as the administrative center of the former khanate, very soon the city became one of the most developed cities in the region in terms of financial and economic issues, such as Tashkent, Andijan, Namangan, Osh, Margilan, etc.

Due to the convenient location at the crossroads of trade routes and the incredible work of both city residents (primarily merchants and artisans, whose products have always been in demand in other cities of the region) and adjacent territories (cities and villages, from other places by merchantsKokands of goods of a daily and seasonal nature) the city becomes such, i.e. retained its socio-economic status. Even at this time, Kokand was not only a large city in the Fergana region, but also became one of the largest cities in Turkestan.

The city, surrounded by large adobe walls, is located in a very convenient and beautiful area, in the gos of the XIX century more than 80 thousand people lived in the city [9:]. Even the guests of the city who came here in the late 19th - early 2oth centuries spoke about the convenient location and the beauty of the city's nature [7: p.51]. There were many large and small gardens and reservoirs around the city and on its territory. Especially famous for this was the large garden that belonged to the khans, which contained almonds, vineyards, peach, apricot and other trees.

The city of Kokand differed from some other cities in the valley in that there was a small Russian-speaking population, so the district administration did not pay attention to the construction and improvement of the city. But, despite this, from the end of the 19th century, 
the city was embellished with buildings for a European maneuver, these were bank buildings, shopping arcades and houses of large entrepreneurs, as well as public buildings, but the city remained faithful to the traditions of Central Asian urban planning for a long time.

Since ancient times, the inhabitants of the city had historical experience in the field of melon growing, horticulture, silkworm breeding, pottery production, embroidery of skullcaps, production of copper products, possessed skills and other crafts, and also engaged in trade.

Among the markets in the Fergana Valley, the Kokand market was in the first place and was distinguished by its retail price and variety of products. Even people living outside the city came to this particular market after walking several kilometers.

In the city of Kokand, market relations with Kashgar (Koshigar), Bukhara, Khiva and Russian cities have retained a significant role. The goods brought from Kashgar were sent to the Fergana Valley, to the cities of Kokand and Margilan, and it was from here that they were distributed throughout Turkestan [5: p.45-48].

Thus, it can be argued that in the field of market relations, Kokand ranked first in comparison with other cities not only in the Fergana Valley, but in the entire Turkestank region as a whole. The traditional crafts of the city of Kokand were sericulture, jewelry, blacksmithing and pottery, the production of weapons and paper, weaving, embroidery and skullcaps, the construction of bridges, etc.

Besides, the leading role in trade relations between Kashgar and Fergana (Kokand) was occupied by trade in silk fabrics. In 1914 alone, goods worth 3,410,000 rubles were imported from Kashgar to Fergana, such as silk and other types of fabrics, felt, leather items, carpets, black tea and other products. From Fergana to Kashgar in 1914, goods worth 3,624,000 rubles were sent, consisting of such items as: cotton and silk fabrics, objects made of iron and steel, various types of glass products, matches, tobacco products, sewing machines, velvet and silk fabrics [16: p.103].

Naturally, trade routes to Kashgar could pass through many cities in the valley. V.V. Velyaminov-Zernov wrote that "every year they bring from Kashgar to Kokand: 30,000 horses for tea, green, brick and akkuyruk (low grade phymal), 200 horses for white felt, 200 horses for alum, 50 horses for Chinese cups and 50 horses for groceries" [ 3: p. 130].

According to M.Venyukov: "Various paper fabrics, dressing gowns, coarse calico, garbage, dried berries, etc. are delivered from Kashgar, especially coarse calico and paper Armenian clothes of yellow, black and brown colors. All these goods with great profit for merchants are exchanged for rams, 15 yards in order to be exchanged for a ram, and a canvas of paper Armenian for 4-5 rams, depending on kindness "[4: p. 111].

The road from Kashgar to Kokand took 23 days. As a rule, caravans departed at the beginning of June and consisted of 1,000-1,500 horses loaded with goods; camels were used only to transport tents, clothing, and travel supplies and supplies. There were Kabul, Persian, Bukhara, Kokand and Tashkent merchants in the caravans [17: p.348].

Studying trade relations among the Kyrgyz people, A.P. Khoroshkhin wrote: "Many tens of thousands of sheep come to Kokand through Aulie-Ata from the Kyrgyz steppes, and from Tashkent come Russian fabrics of manufactured goods, sugar, iron, etc." [35: p.177]. 
Naturally, in this process, an important role belongs to the city of Kokand.Sericulture continues to be engaged at the present time. To develop the quality of sericulture, not only scientific means, but also traditional experience were widely used. In terms of silk quality, Kokand ranked second after Margilan among the cities of the Fergana Valley. Silk fabrics were taken from Kokand and Margilan to Marseille (France), Constantinople and to the European part of Russia [6: p.190-191]. Also, silk fabrics were in demand in countries such as India and Iran. Silk especially played an important role in market relations with Russia. The demand for silk grew year after year. For example, only in the Kokand district in 1906, 28,962 poods of raw cocoons were produced, which is equal to 376,506 rubles of the empire of that time [21: p.31]. Or, in the same year, cocoons worth 24,866 rubles were sold both to the domestic and foreign markets [22: Ibid.], Silkworm breeding in the amount of 1,400 rubles, then in 1885 this amount was already 228,000 rubles. [15: p.115-146, 188-190] while almost all silkworms were handicraft, and in Kokand, taking into account the villages included in the county, there were 70 silkworms, the annual productivity of which was equal to 32245 rubles [23: p.32].

They were exported to Russia and abroad, it should be taken into account that which part was purchased from the city's artisans employed in this area. In addition, various fabrics, leather and fur, skullcaps were exported from Kokand to Russia, and iron, paints, sugar, and industrial products were supplied to Kokand from Russia. Kokand, like other cities of Turkestan, was the main food source of the metropolis.

Sericulture brought income not only to Russian entrepreneurs, but also to the government. In the late XIX-early XX centuries. in the city there were 20 silk-winding factories, engaged exclusively in silk weaving, which mainly belonged to the local population and about 140 weaving and dyeing workshops [10: p.315]. In addition, the manufacture of adras, muslin and other types of fabrics was widely developed in the city.

Only 4 small cotton ginning workshops, silk spinning workshops and a branch of the Russian-Chinese Bank operated in the city. The main owners of commercial and industrial enterprises in the cities of the Fergana Valley, such as Andijan, Namangan, Osh, Margilan, were representatives of indigenous nationalities, representatives of Russian and foreign companies. In Kokand, the bulk of the commercial and industrialists were also representatives of the local population, and especially Jews [20: p.67].

By January 1, 1906, the following data are provided on the movement of city public funds: at the beginning of the year, the city budget had an amount equal to 136,431 rubles, during the year 113,080 rubles were received, 126,023 rubles were spent, and by January 1 of the following year there were 121,461 rubles [26: $p$. 75]. In general, the annual trade turnover of Kokand was at all times positive in favor of export (i.e. - export - author's note).

If at the end of the XIX century this amount was expressed in the amount of 4-5 million Russian rubles [11: p.420], then there is no doubt that by the beginning of the $X X$ century this amount increased many times. This indicates a positive balance of revenues and expenditures of the city budget and clearly shows the economic state of the city.

Thus, the county administration spent very little on urban needs, in particular on education, police and sanitary conditions of the city. All schools have been renovated with the 
help of local entrepreneurs, with wakuf property and with the help of the students' parents. The city administration did not pay attention not only to education, but also to the construction and improvement of the city. The generosity of local, authoritative owners or beys played a significant role in situations such as solving socio-economic problems.

One of the widespread industries was the manufacture of oils, as a result of which in the Kokand district at the beginning of the 2oth century the number of oil mills doubled. Compared to oils made at the oil factories of Russian and local entrepreneurs, the needs of the population were satisfied by the oils and oil products of local factories. In general, in comparison with other cities of the valley, there were few industrial facilities in Kokand. In the 80 s of the XIX century. in the city and in its environs there were about 15 cotton ginning enterprises [12: $\mathrm{p}$. 315-320].

However, all the active economic changes that took place on the territory of the Fergana Valley seriously affected the life of the city, such industries as winemaking, cotton growing, and silkworm growing began to develop extensively. Along with them, viticulture began to develop widely, since at this time, the development of winemaking proceeded at a rapid pace, and the need for grapes grew. As a result, the number of vineyards in the city increased. So, the territory of the Kokand district in 1906, 3,318 acres of area were allotted for gardening, viticulture, melon growing and horticulture [28: p.23]. This one was slightly smaller than the Andijan area, but almost equal to the Margelan and Namangan areas taken together. It can be safely asserted that although the harvest from these lands was low due to poor care or a low variety of local fruits, it fully satisfied the internal need of the population for these products.

In general, it should be borne in mind that from the last quarter of the 19th century until the First World War, the amount of product obtained from grapes and other fruits increased. So, for example, if in 1880 the number of grapes grown was 93,000 poods [18: P.10], then by 1897 this figure reached 352,000 poods [19: P.5], and in subsequent years it increased even more. If earlier on the territory of Kokand grapes were consumed in dried form, then later they began to make wine.

The population of the city grew year after year. So if in 1882-1883. the population of the city was about 55 thousand people [13: p. 421], then in 1910, a couple of decades later, the population of the city almost doubled and amounted to 115600 people (of which 64222 men and 51,378 women) [27: p.2]. Nationally, apart from Uzbeks and Sarts, they were Russians (228 people), Germans (5 people), Poles (3 people), Jews (320 people), Gypsies (400 people), Afghans (15 people). ), Dungans (60 people), Indians (22 people), Sarts (we think the same about themselves as Uzbeks the author) (50600 people), Kyrgyz (400 people), Tajiks (2500 people) [28: Ibid]. If we take into account that in general in the Kokand district in these years about more than 140 thousand people of the population lived, it turns out that about $20-30 \%$ of the population lived in the city of Kokand. For the period from 1897 to 1907, from all the cities of the Fergana Valley in the cities of Andijan and Kokand, there is an increase in the urban population, which is explained by socio-social and economic statuses, including possible changes in the infrastructure of these cities, then in some others - in Skobelev, Namangan, Osh this indicator has a decrease, and in other cities - in 
Margilan and Chust it remained unchanged [29: P.15].

As mentioned above, according to official data, in 1897 there were about 86,000 people in the city, and by 1910, the population had reached more than 90,000 people [25: P.170]. However, the funds allocated for the social life of the city were not enough.

Although rural medicine was introduced throughout the Fergana region in 1906, there was a shortage of medical personnel in the cities. Thus, there were 2 doctors working in the city: a man and a woman, 3 male paramedics and, respectively, 2 women, 1 dentist and 6 pharmacists [31: p.93], which was not enough for the growing population of the city.

In this indicator, the city of Kokand also had positive shifts. That is, a year later, 5 doctors already worked in the city: men (4) and women (1), 2 male paramedics and 3 women, respectively, 1 dentist and 7 pharmacists [33: C.101] In Kokand at the beginning of XX there were very few hospitals in the century. For example, in 1906 in the city there was a city hospital with 20 beds and a women's hospital with 10 beds [34: Ibid., P. 95]. Despite the small number of medical services, the city's climate was clean and fresh, which contributed to the low incidence of diseases. People came from neighboring towns and villages to Kokand to be treated.

In conclusion, we can say that in the late XIX early XX centuries in the city of Kokand there were significant changes in comparison with other cities of the Fergana Valley.

This was facilitated by the emergence of the Russian-speaking population in the city, the opening of many institutions by the commercial and industrial community, for example, banks built on the European maneuver, the opening of firms, the construction of shops and shops along the city streets, some of them have survived to this day and still serve the townspeople. As a result of the accelerated development of the production of food products and their processing, bringing them to the markets of the empire, this did not prevent the continuation of the centuries-old traditions of local handicrafts, especially sericulture and some other types, but, on the contrary, contributed to their optimization.

The city independently supported its economic, social and cultural life with the help of local entrepreneurs and noble people, which, of course, was also facilitated by the work and centuries-old experience of the people. Thanks to this, the local population has preserved national and historical traditions.

Thus, the socio-economic and political changes that took place in the colonial and Soviet period manifested themselves in the life of the city of Kokand and, naturally, in other cities of the Fergana Valley. In 1917-1924, there were noticeable changes in the trade industry of the cities of the Fergana Valley.

Despite the conditions of economic dependence and political lawlessness, the impossibility of fully manifesting its potential by the population of the cities of the Fergana Valley, it was able to show the features of hard work and love of freedom and preserve the existing national culture and values and pass it on to future generations.

\section{REFERENCES}

1. Bobobekov $\mathrm{H}$. The history of Kokand. Science, 1996.p. 7.

2. Velyaminov-Zernov V.V. Information about the Kokand Khanate // Bulletin of the 
Russian Geographical Society. 1856. - Ch. 18. - Book. 5. - p. 130.

3. Velyaminov-Zernov V.V. Information about the Kokand Khanate // Bulletin of the Russian Geographical Society, 1856. - part. 18. - Book. 5. - p. 130.

4. Venyukov $M$. Essays on the Zailiyskiy Territory and the Prichui Country // Notes of the Russian Geographical Society. Book. 4. - 1861. - p. 111.

5. Yearbook of the Fergana region. Volume I. Issue 1902. New Margelan. 1902.S. 45-48.

6. Yearbook of the Fergana region. Volume I. Issue 1902. New Margelan. 1902. C.190-191.

7. Murakhina L. Across Central Asia and Tibet: The Journey of Sven Khedin. Around the world. 1899. No. 3, P.40-51.

8. Nalivkin V.P. A Brief History of the Kokand Khanate. Kazan, 1886.

9. Population of the empire according to the census on January 28, 1897 by counties. The first census of the population of the Russian Empire in 1897.1897.

10. On Uz. I.19-fund, op.1, D. - 1170 L. -315.

11. On Uz. I.19-fund, op.1, D. - 1170 L. -420.

12. On Uz. I.19-fund, op.1, D. - 1170 L. - 315-320.

13. On Uz. I.19-fund, op.1, D. - 1170 L. -421.

14. On Uz. I.19-fund, op.1, D. - 1170 L. -421.

15. AT Uz. 23-fund, D. - 470, L. - 188-190, 115-146.

16. At Uz, fund - R.37, inventory - 1, file - 409, sheet - 103.

17. Nebolsin P.I. Essays on trade between Russia and Central Asia // Zap. IRGO. - Book. 10. - SPb, 1855 --- P. 348.

18. Review of the Fergana region for 1890. New Margelan. 1893, p. 10.

19. Review of the Fergana region for 1897 . New Margelan, 1899, p. 5.

20. Statistical review of the Fergana region for 1905. Skobelev 1908, p. 67.

21. Statistical review of the Fergana region for 1906. Skobelev 1908, p. 31.

22. Statistical review of the Fergana region for 1906. Skobelev 1908, p. 31.
23. Statistical review of the Fergana region for 1906. Skobelev 1908, p. 32.

24. Statistical review of the Fergana region for 1906. Skobelev 1912, p. 93.

25. Statistical review of the Fergana region for 1906. Skobelev 1912, p. 95.

26. Statistical review of the Fergana region for 1906. Skobelev 1908.p.75.

27. Statistical review of the Fergana region for 1910. Skobelev 1912, p. 2.

28. Statistical review of the Fergana region for 1906. Skobelev 1908, p. 23.

29. Statistical review of the Fergana region for 1907. Skobelev 1909, p. 15.

30. Statistical review of the Fergana region for 1910. Skobelev 1912, p. 170.

31. Statistical review of the Fergana region for 1906. Skobelev 1912, p. 93.

32. Turkestan collection. T. 38, p. 282.

33. Statistical review of the Fergana region for 1907. Skobelev 1909, p. 101.

34. Statistical review of the Fergana region for 1907. Skobelev 1909, p. 95.

35. Khoroshkhin A.P. Essays on Kokand // Turkestan collection. - T. 23,1870 .-- S. 177. 